The Geographical Journal of Nepal

Vol. 12: 41-56, 2019

Central Department of Geography,

Tribhuvan University, Kathmandu, Nepal

\title{
Landscape dynamics in the northeast part of Andhikhola watershed, Middle hills of Nepal
}

\author{
Chhabi Lal Chidi ${ }^{*}$, Wolfgang Sulzer², Pushkar Kumar Pradhan ${ }^{1}$ \\ ${ }^{1}$ Central Department of geography, Tribhuvan University, Kathmandu; \\ ${ }^{2}$ Institute of Geography and Regional Science, University of Graz, Graz, Austria
}

(*Corresponding Author: chidichhabilal@gmail.com)

\begin{abstract}
Depopulation and increasing greenery due to agriculture land abandonment is general scenario in many highlands of Nepal in recent decades. High resolution remote sensing image is used in land use change analysis. Recently, object based image analysis technique has helped to improve the land use classification accuracies. Thus, this study was carried out with high resolution image data sources and innovative technique of land use classification in the northeast part of Andhikhola watershed, in the Middle Hill of Nepal. Increasing greenery due to agriculture land abandonment in the hill slope is the major land use change. Secondly, increasing built-up area in lowland along the highway is another. Decreasing hill farmers is the major drivers of converting cultivated land into vegetated area and increasing built-up area is due to urbanization and shift of rural people from hill slope to lowland and accessible area. Converting cultivated land into forest, shrubs and grassland is at marginal land and remote areas which is mostly controlled by altitude, slope gradient and slope aspect. Additionally, land suitability and accessibility are also other important controlling factors.
\end{abstract}

DOI: http://dx.doi.org/10.3126/gjn.v12i1.23415

Keywords: high-resolution, land use, object-based image analysis, remote sensing images

\section{Introduction}

A landscape is the visible feature of an area of land which reflects a living synthesis of people and place helping to understand self-image of the people who habitat it (Higgins 
et al., 2012). Land use/land cover (LU/LC) is the spatial pattern of landscape (Higgins et al., 2012). Thus the dynamics of land use/land cover are fundamental to monitor physical and human processes on a land system, which is very essential for human well being and sustainable environmental management (Shreenivasulu et al., 2014). Agriculture landscape is very much human-driven, which is studied in the form of land use/land cover dynamics (Barton et al., 2010). The population in mountain and hill was increasing (Clarke, 1990) resulting high population pressure on traditional intensive subsistence farming two decades before. The implication of population growth is the increasing demand for agriculture land for food, forest products for fuel, fodder, leaf and litter and pasture land. Encroachment of marginal land for cultivation, deforestation, and overgrazing in the hill slopes of Nepal has led to widespread erosion and massive destruction of forest (Blaikie et al., 1980; Eckholm, 1976). Consequently, the subsistence agrarian economy in the Hills of Nepal has increasingly been vulnerable due to the deterioration of environment and ecology (Mauch, 1976; Rieger, 1976; Schroder, 1977). Heavy loss of precious top soil reducing the productivity of agriculture land in the hill slopes, with scarcity of forest and grazing lands (Ives and Messerli, 1989) has led to increasing poverty, particularly among the marginal hill farmers. Over the last two decades, migration of rural farmers from the Hill to the Tarai and towns and cities within the country, as well as to foreign countries has decreased the population pressure on the hill slope agriculture of Nepal (CBS, 2012). Tendencies of out migration of rural farmer in search of employment to foreign countries and urban areas are highly increasing (CBS, 2012). This development is accompanied by increasing greenness in such abandoned agriculture land and can be observed elsewhere in poor developing countries across the world in the recent decades (Gellrich et al., 2007; Li et al., 2018; Shi et al. 2017). Such phenomena can also be detected in the Hills of Nepal (Chidi, 2015; Chaudhary, 2018). Depopulation is being the major driver of cultivated land abandonment and increasing natural vegetation cover in Andhikhola watershed of Syangja district (Chidi, 2016) and the spatial pattern of land use change is highly different at different land features. However, micro-level analysis of land use land cover change is still lacking. Thus, this study aims to analyze land use change in the northeast part of Andhikhola watershed of Syangja district using high resolution image and latest land use classification techniques.

\section{Data and methods}

This study is concerned on land use change analysis, for which the data have been analyzed from high resolution remote sensing image and object based image analysis technique. Population data was collected from population census reports. Field work was carried out for verification, correction of collected data, and the identification of 
ground reality. Basic spatial information such as contour lines, drainage system, road network and settlement were derived from the topographical map (1996) at the scale of 1:25000 from Survey Department of Nepal. These were converted into digital format. The Digital Elevation Model (DEM) was developed using 20-meter interval contour lines of the topographic maps. Altitude, slope aspect and slope gradient information were derived from DEM. The aerial photos of 1996 (collected from Survey Department of Nepal) covering the study area were converted into Orthophoto (ERDAS, 2010). The orthophoto was used to derive land use (Lillesand et al., 2011; Lawali and Dauda, 2014) in 1996. WorldView 2 image of 2011 with 2 m multispectral spatial resolution and the $0.5 \mathrm{~m}$ panchromatic spatial resolution was used to obtain recent land use information. Resolution merge (data fusion) of the multispectral bands with the panchromatic band was carried out to generate $0.5 \mathrm{~m}$ image data (Table 1).

Table 1: WorldView 2 image information

\begin{tabular}{|c|c|c|c|}
\hline Image description & $\begin{array}{c}\text { Multispectral (8 } \\
\text { bands) }\end{array}$ & $\begin{array}{c}\text { Wave } \\
\text { length }(\mathrm{nm})\end{array}$ & $\begin{array}{c}\text { Spatial } \\
\text { resolution }\end{array}$ \\
\hline \multirow{4}{*}{ Imagery source: WV2 } & Coastal & $400-450$ & \\
\hline & Blue & $450-510$ & \\
\hline & Green & $510-580$ & \\
\hline & Yellow & $585-625$ & \\
\hline \multirow{5}{*}{$\begin{array}{l}\text { Radiometric resolution: } 11 \text { bits } \\
\text { Catalog ID: } \\
\text { 1030010010146A00 \&103001000F8FE300 }\end{array}$} & Red & $630-690$ & \\
\hline & Red Edge & $705-745$ & \\
\hline & Near-IR1 & $770-895$ & \\
\hline & Near-IR2 & $860-1010$ & $2.0 \mathrm{~m}$ \\
\hline & Panchromatic & $450-800$ & $0.5 \mathrm{~m}$ \\
\hline
\end{tabular}

Object-based image analysis (OBIA) on a high-resolution image was used to achieve higher accuracy for the land use/land cover change classification (Blaschke, 2010). Threshold algorithm was used for image classification in OBIA. The land use was classified into six broad classes such as forest, shrubs, grassland, cultivated land, sandy and water. Observation was carried out for the correction of land use derived from the image of 2011 to develop the land use of 2016, and to know the ground reality in the study area. Seventeen locations were selected at different geographic locations on the basis of altitude, distance from market, and different parts of the hill slopes. Detail field study was carried out with semi structured questionnaire using Reality Check Approach (RCA) at these selected settlements (Jupp et al., 2016; RAP, 2015). From each selected settlements, three households of economically poor, middle and rich were selected for 
RCA. In the meantime, informal discussions were also held with the local people of those locations and acquired information about the change in land use classes and their associated factors.

Maps and tables of land use and change in 1996 and 2016 were derived. Land use transition matrix was developed to identify the land use transformation from one category to other during 1996 to 2016. Separate land use of 1996 and 2016 at different altitude, slope gradient and slope aspect were also calculated to identify the control of these topographic variables on land use change. Forest, shrubs and grass land was grouped into vegetated area.

\section{The study area}

The study area is the northeast part of the Andhikhola watershed of Syangja district, lying in the southwestern part of Narayani watershed of Nepal. The study area covers nearly 97.8 square kilometers, comprising altitudes ranging from 779 meters to 2,469 meters (Figure 1). The Andhikhola is one of the tributaries of the Kaligandaki river that finally drains to the Narayani river. The study area lies within $28^{\circ} 03^{\prime} 40^{\prime \prime}$ north to $28^{\circ} 11^{\prime} 02^{\prime \prime}$ north latitude and $83^{\circ} 49^{\prime} 30^{\prime \prime}$ east to $83^{\circ} 56^{\prime} 51^{\prime \prime}$ east longitude. Over $30 \%$ of the land of the study area is occupied by less than $5^{\circ}$ slope angle, while more than half $(52.53 \%)$ of the area shows a slope angle ranging from $5^{\circ}$ to $30^{\circ}$. About $17 \%$ land is steeper than $30^{\circ}$.

The study area lies in a subtropical and warm temperate region having an average temperature of $21^{\circ} \mathrm{C}$ with a range of minimum average $12^{\circ} \mathrm{C}$ in winter to maximum average $27^{\circ} \mathrm{Cin}$ summer (DHM, 2009). It receives a total annual precipitation of 2,800 $\mathrm{mm}$ in which about $80 \%$ rainfall occurs during the summer season from June through September. Lower plain area has irrigation facility from the river and stream where crops are produced thrice in a year. Only few parts of hill slopes have seasonal irrigation facility where crops are produced twice a year. Other areas are rainfed area with only one season crop. The average population density watershed is 324 persons per sq. km ranging from 30 persons in remote hill slopes and 3,404 persons per sq. km in urban area (CBS, 2012). Traditional intensive subsistence agriculture practice is the major occupation in the study area similar to other parts of mountain and hills of Nepal. 


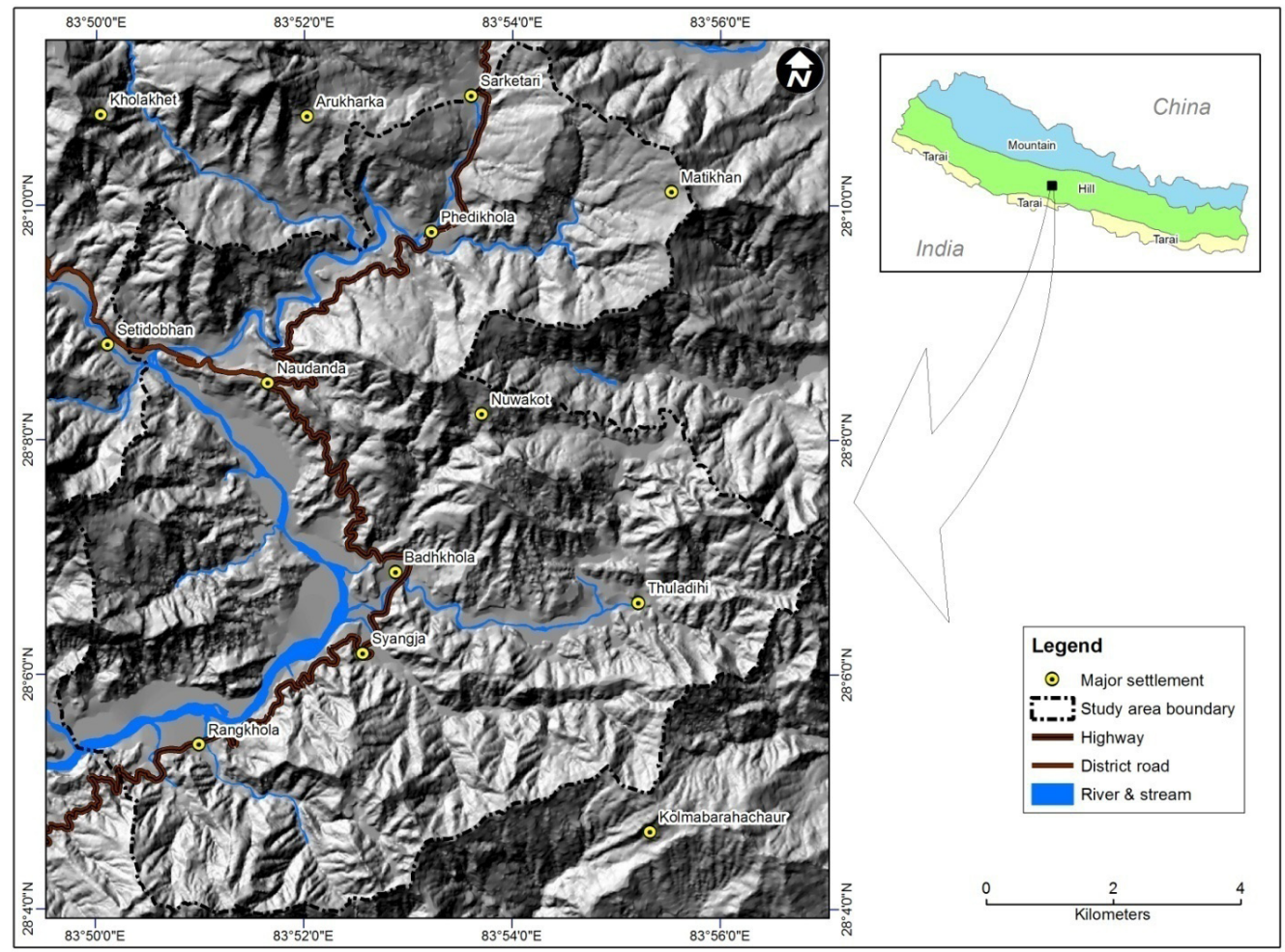

Figure 1: The study area

\section{Results}

\section{Human population}

The annual growth rates of population in Syangja district were $0.77 \%$ between 1981 to 1991 and $0.78 \%$ between $1991-2001$ which was less than the national average of Nepal $2.1 \%$ and $2.25 \%$ respectively. But during 2001 to 2011, the annual population change rate of Syangja district was -0.93 (CBS 2012) whereas national rate of change was 1.35. Nearly $50 \%$ of the households had at least one family member absent in Syangja district in 2011 as compared to $25 \%$ of the households at the national level. The absent population of Syangja district was $17.5 \%$ which is quite higher than that of national level $(7.3 \%)$ and the rural area (7.4\%) (CBS, 2012). The analysis of some portion of the study area revealed that $47 \%$ of active age population are absent from the village in 2015 (Chidi, 2015). In Nepal, history of migration of population in foreign countries is not new. However, it emerged more rapidly in the mid 1990s as a foreign employment among the youth became motivating factor because of the political instability due to the Maoist insurgency in Nepal on the one hand and rapid growth of development activities 
in the countries of East Asia and Gulf region which created employment opportunities for skilled and unskilled labor on the other hand. Nepalese obtained official permission to work in oversea countries more than double between 1996/1997 and 1997/1998. Nepalese in foreign employment was estimated around 2.27 million in 2007 (NCCR/ NIDS, 2008). The active members of most of the families receiving remittance from foreign employments are found living in the towns and cities of the districts across the country for relatively better facilities such as education, health, accessibility by public transport, security, etc (Pradhan and Sharma, 2017). Indeed, most of the rural areas of Nepal grossly lack these basic facilities. As a result, only the old aged people are living in the rural villages to look after their ancestral properties.

\section{Land use change}

Cultivated land is highly decreasing at the hill slope converting into forest and shrubs. There is no significant change on cultivated land at lowland area. Built-up area has significantly increased along the highway and river side. Forest and shrub has been significantly increased in most of the sloppy land (Figure 2). The maps indicate that lower plain and accessible area has the lowest change of land use than remote hill slopes.

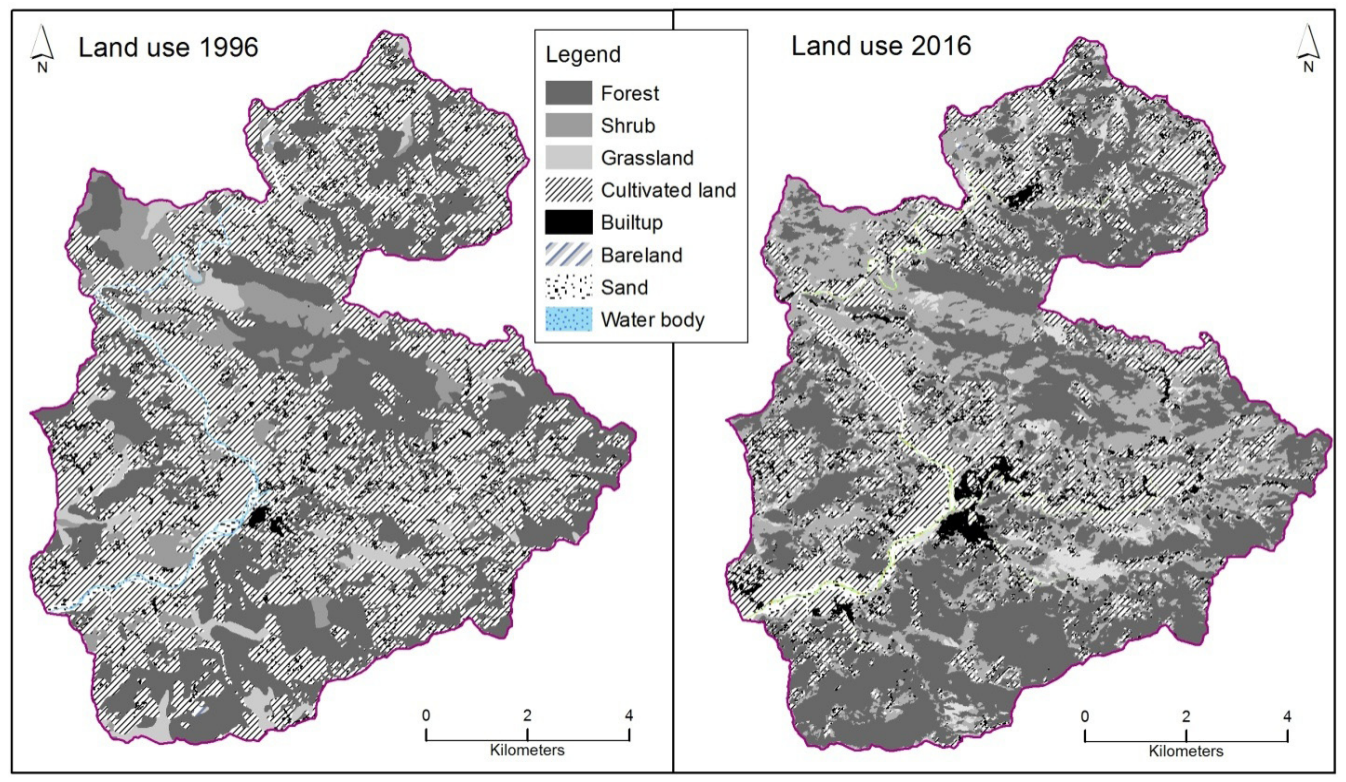

Figure 2: Land use pattern in 1996 and 2016 
Nearly $57 \%$ of the total study area is covered by cultivated land followed by forest. Forest and cultivated land occupied nearly $88 \%$ of the total area in 1996 . The third and the fourth land use types are shrub and grassland. Vegetated area (forest, shrubs and grass land) occupied more than $40 \%$ of the total area. Altogether nearly $97 \%$ of the total area was occupied by cultivated land and vegetated area in 1996. Remaining was covered by built-up area, sand and water. But in 2016, forest area was the highest followed by cultivated land and shrub area. Built-up area increased more than double (Table 2).

Table 2: Land use and change

\begin{tabular}{|l|r|r|r|r|r|}
\hline \multirow{2}{*}{ Land use } & \multicolumn{2}{|c|}{ Area (Sq. $\mathbf{~ k m})$} & \multicolumn{2}{c|}{ Area \% } & \multirow{2}{*}{$\begin{array}{c}\text { Change } \\
\text { \% }\end{array}$} \\
\cline { 2 - 5 } & $\mathbf{1 9 9 6}$ & $\mathbf{2 0 1 6}$ & $\mathbf{1 9 9 6}$ & $\mathbf{2 0 1 6}$ & \multicolumn{1}{c|}{} \\
\hline Forest & 30.10 & 38.12 & 30.80 & 39.00 & 26.6 \\
\hline Shrub & 5.92 & 26.77 & 6.06 & 27.39 & 352.0 \\
\hline Grass & 3.44 & 2.50 & 3.52 & 2.56 & -27.3 \\
\hline Cultivation & 55.47 & 26.79 & 56.75 & 27.41 & -51.7 \\
\hline Built-up & 0.70 & 1.45 & 0.72 & 1.48 & 105.6 \\
\hline Sand & 1.54 & 1.50 & 1.57 & 1.53 & -2.6 \\
\hline Waterbody & 0.56 & 0.54 & 0.58 & 0.55 & -5.2 \\
\hline Total & $\mathbf{9 7 . 7 5}$ & $\mathbf{9 7 . 7 5}$ & $\mathbf{1 0 0 . 0 0}$ & $\mathbf{1 0 0 . 0 0}$ & \\
\hline
\end{tabular}

Table 2 indicates that there is a significant change in land use in the study area between 1996 and 2016. Shrub area has increased tremendously with over $352 \%$ during this period. This is followed by the forest coverage and built-up areas (Table 2). On the other hand, area of two land use types such as agriculture land and grassland has decreased remarkably during this period. It has been observed that most of the grassland was converted into shrub.

\section{Land use transformation (1996-2016)}

The highest proportion of the transformed cultivated land is into the shrubs followed by forest and grass. More than $51 \%$ of the total cultivated land of 1996 was converted to vegetated area (forest, shrub and grassland). Some portion was into built-up and others. Conversion of forest area to other land use is the lowest. Higher proportion of shrub was transformed into forest, and grass into forest and shrubs. Built-up area was transformed into cultivated land and shrub. Due to its small proportion of the total area, 
it has no significant impact on percentage area change in total. However, 2.18 percent transform of cultivated land into built-up area has significantly increased during 2001 to 2016 (Table 3).

Table 3: Percentage of land use transformation (1996-2016)

\begin{tabular}{|l|r|r|r|r|r|r|r|}
\hline \multicolumn{1}{|c|}{ Land use } & Cultivation & \multicolumn{1}{c|}{ Built up } & \multicolumn{1}{c|}{ Forest } & \multicolumn{1}{c|}{ Shrub } & \multicolumn{1}{c|}{ Grass } & \multicolumn{1}{c|}{ Sand } & Water \\
\hline Cultivation & $\mathbf{4 5 . 4 5}$ & 2.18 & 19.95 & 29.06 & 2.20 & 0.90 & 0.26 \\
\hline Built up & 45.78 & $\mathbf{2 9 . 1 4}$ & 8.01 & 16.43 & 0.57 & 0.06 & 0.01 \\
\hline Forest & 2.11 & 0.08 & $\mathbf{8 0 . 0 6}$ & 17.30 & 0.38 & 0.05 & 0.02 \\
\hline Shrub & 2.07 & 0.05 & $\mathbf{3 4 . 6 1}$ & $\mathbf{6 0 . 8 4}$ & 2.13 & 0.14 & 0.17 \\
\hline Grass & 2.04 & 0.07 & 26.86 & 43.15 & $\mathbf{2 7 . 7 1}$ & 0.08 & 0.09 \\
\hline Sand & 24.13 & 0.37 & 2.80 & 11.32 & 4.04 & $\mathbf{4 2 . 8 6}$ & 14.46 \\
\hline Water & 16.43 & 0.44 & 0.34 & 15.06 & 3.18 & $\mathbf{4 2 . 4 6}$ & $\mathbf{2 2 . 0 8}$ \\
\hline
\end{tabular}

\section{Land use and topography}

Cultivated land has been deceased in all slope aspects, slope gradient and elevation in the study area. However, the proportion of change is highly different at different elevation, slope gradient and slope aspects. The highest proportion of cultivated land has decreased in the north facing slope (more than 70\%) followed by the northeast and the northwest. Least change is in the flatland followed by south and southeast. The proportion of vegetated area highly increased at flatland followed by east and west facing slopes. Built-up area highly increased in the flatland followed by west. Decreasing of cultivated land is the highest above 1300 meters and the least at below $900 \mathrm{~m}$. Built-up area increased more than double below 900 meters. Similarly, increasing vegetated area is the highest below 900 meters (Figure 3). 


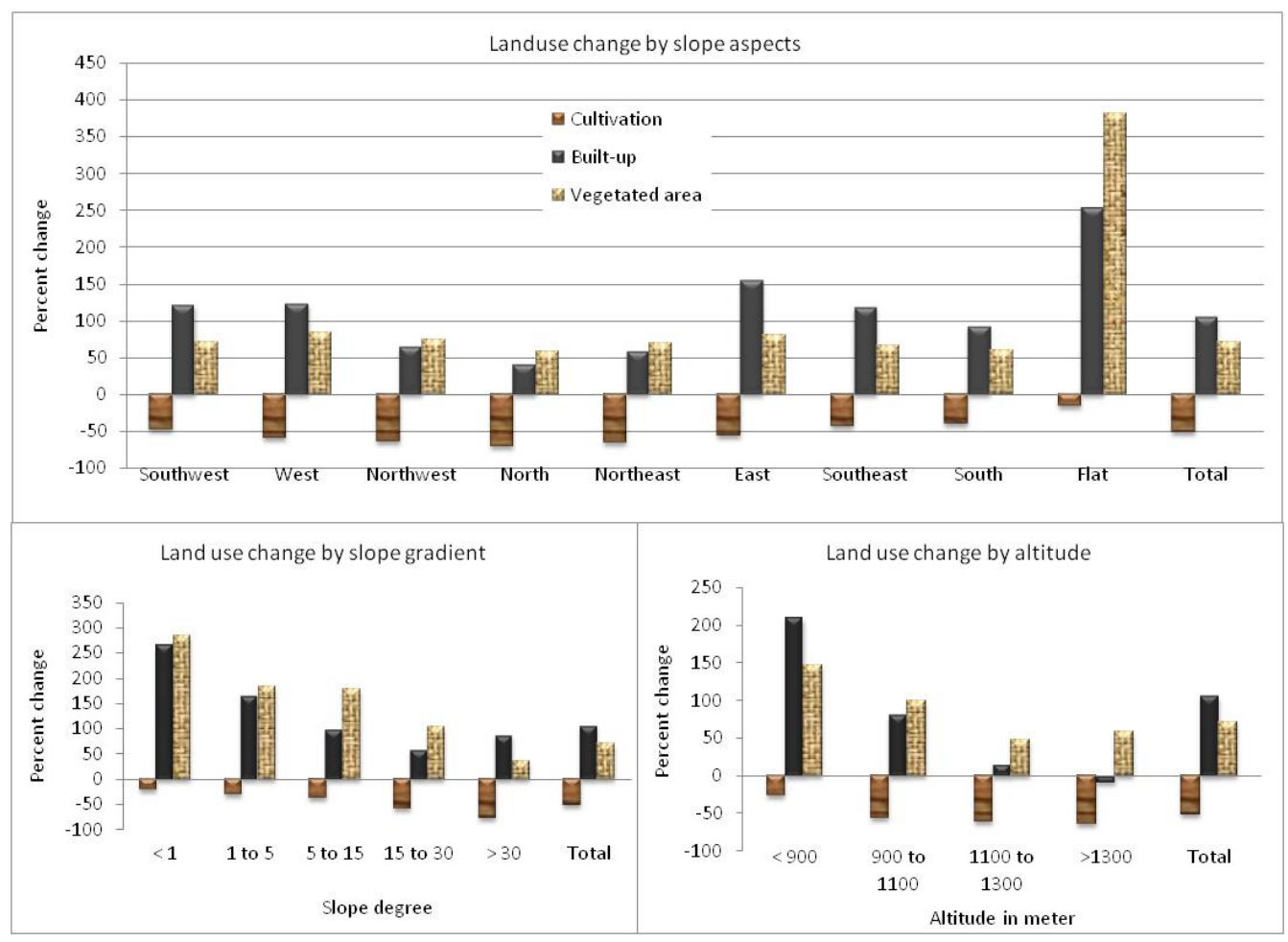

Figure 3: Land use change by altitude, slope gradient and slope aspect

Decreasing grassland coverage was due to the conversion of grassland into shrub. Builtup area has been increased remarkably mainly in the lowland, because of the spatial shift of people from traditional settlements of the hill slopes to the lowland and along roads and highways. As a result, rapidly growing urbanization process in these areas can be detected (Figure 2). In 2016, land use map shows a more complex pattern compared to the 1996 map. This is caused by the abandonment of agriculture patches, converting them into green areas such as forest, shrubs, and grassland. Land use change analysis shows that higher parts have more land abandonments of cultivated land converting into vegetated area. Increasing built-up area can be detected in lowlands. Most cultivated land has been converted into forest, shrub and grassland. Some parts of the cultivated land of 1996, now became forest coverage because those parts within the cultivated land had already some upcoming trees in the old image.

Conversion of cultivated land into a vegetated area is highly correlated with depopulation in the watershed during 1999 to 2014 (Chidi, 2016). The land use change during this period shows that the significant decrease of cultivated land and increase of vegetated 
area due to the agriculture land abandonment in the study area can be compared with many highlands having similar phenomena in the world (Shengfa and Xiubin, 2017; Gellrich et al., 2007; Prishchepov et al., 2013). Thus, this study result is not also different from many other findings in the world.

\section{Discussions}

There is an intrinsic relationship between human activities and their surrounding landscape. Agriculture through hill terrace farming system is the main occupation and major means of the main income for the rural farmers in the study area. Agriculture system has however, not been improved due to the lack of agro-infrastructure. For instance, the study area had its 21.6 percent cultivated land being irrigated by perennial irrigation system (DADO, 2013). Subsistence agriculture has been practiced by the farmers, which was just to produce goods required to feed their families themselves. Further, landholding size was characterized by extremely small farm size having 0.51 hectare in Syangja district, which was quite lower than the national figure (CBS, 2013). Despite there is comparably higher comparative advantage in diversity of cropping practice due to the altitudinal variation, weather change, source of water, biodiversity, etc, the highlands of the hill areas have not exploited these benefits are due to the lack of basic agro-infrastructure. Control of topographic factors such as elevation, slope gradient and slope aspect converting agriculture land to vegetated area is found in many parts in the world (Chidi, 2016; Birhane et al., 2019). Major permanent restrictions of agriculture in mountain areas are the natural landscape with their steep slope, climate, and altitude (European Commission, 2009). Heavy loss of hill farmers during the last two decades is caused by scarcity of agriculture land and lack of off-farm job opportunities in the uplands and expanding commercial farming in the lowlands, growing economies in urban areas and foreign countries (Pratap, 2011; Fatima and Hussain, 2012; Barah, 2010) as elsewhere in large parts of world (Tukahirwa, 2002; VanWey, 2003). Lack of sufficient land for cultivation, low productivity and other facilities has motivated farmers to out-migration in the study area. Out-migration of the farmers from the hill slope has released population pressure on the farmland, which was already more than land carrying capacity in the past. Degradation of land and natural vegetation including wildlife has been a crucial issue in the hills of Nepal (Blaikie and Brookfield, 1987). Higher human intervention in the hills increased land degradation in the past (Regmi, 1978; Carson, 1985; Mahat, 1985). At that time, overgrazing of livestock on abandoned land had increased land degradation in the hills of Nepal (Khanal and Watanabe, 2006) but now observation reveals that decreasing intensity of livestock number and decreasing human population has resulted into decreasing soil erosion from abandoned land due to mostly covered by vegetation and low intervention of human and livestock. However, 
increasing abandonment of cultivated land has not only caused a decline in the level of agricultural production in the villages but also seriously affected the livelihoods of marginal and small farm households in the villages (Khanal and Watanabe, 2006) in the mountain region of Nepal.

Decreasing human and livestock population resulting into increasing greenery and wildlife population make the suitable situation for interspecies competition (Mackenzie et al., 2002) between wildlife and human population which is common phenomena in many abandoned land (Hua et al., 2016; Benayas et al., 2007). Farmers in the remote areas are facing greater problems from wildlife to protect their farmland and livestock. Usually groundwater recharge is due to increasing natural vegetation (Mohan et al., 2018), but there has been a crucial issue of drying up of water sources due to climate change in Nepal (CBS, 2017; GoN, 2014). Thus, there is not visible impact of ground water recharge due to increasing greenery. However, further scientific verification is required. Depopulation of farmers in the agriculture does not always result in land abandonment, while because of the decreased land value, it is possible to make for land pooling of fragmented small pieces of land holding size for commercial purpose (Ellis, 2004; Izquierdo et al., 2011). Hill slope farmers manage their crops land by terracing, planting vegetation and canalling surface water to protect soil erosion and land degradation. However, down power of summer rainfall sometimes becomes out of control for farmers. For this region, hill farmers require support from outside which will be very helpful for watershed ecosystem in the hill slopes of Nepal. In a watershed ecosystem, highland farmers are responsible for controlling land degradation through the protection of vegetation and proper land management, but they are rarely compensated by lowland people who are benefited due to the better ecosystem services (Bagura, 2012; FAO, 2011). This can be a suitable concept of watershed management in the mountainous country like Nepal.

\section{Conclusion}

In the recent decades, landscape dynamics in the Hills of Nepal is due to the agriculture land abandonment from the Hill slopes and increasing urbanization in the lowland areas. It is because of the out-migration of the farmers to those areas and countries where employment and economic opportunities are offered to them and shifting of people from higher hill slopes to lower plain area, urban centers and Tarai region of Nepal. Landscape dynamic has multi-facet but very few information is available in Nepal. Decreasing human activities in the highland and increasing human activities in low land is the general scenario in the study area. Physical suitability for human habitation as well as accessibility is better in lowland than in the hill slope. Agriculture 
land abandonment in the hills may be beneficial due to the massive regeneration of vegetation, active reforestation, water regulation, soil recovery, nutrient cycling, increasing biodiversity, and wilderness. However, forced change of landscape in the hills may impact on food scarcity and thereby on living of rural people. Many unique opportunities with comparative advantages, which are available in the Hills, need to be exploited by suitable policies and programs that can benefit the hill farmers. Thus, information on landscape dynamics in the hills of Nepal is very essential to be generated through widespread studies which help to formulate policies and plans for sustainable environmental and landscape management.

\section{References}

Barton, C. M., Ullah, I. I., and Bergin, S. (2010). Land use, water and Mediterranean landscapes: Modeling long-term dynamics of complex sociological system. Philosophical Transactions of the Royal Society of Landon, Series A, 368 (1931): 5275-5297.

Bagura, F. K. (2012). Report on progress in implementation of agenda 21 commitments on sustainable mountain development in Africa. Nairobi: United Nations Environment Program.

Barah, B. C. (2010). Problems and prospects for mountain agriculture. Indian Journal of Agriculture Economics, 65 (3): 585-601.

Benayas, J. M. R., Martins, A., Nicolau, J. M. and Schulz, J. J. (2007). Abandonment of agricultural land: An overview of drivers and consequences. Perspectives in Agriculture, Veterinary Science, Nutrition and Natural Resources, 2 (057): 1-14. doi: 10.1079/PAVSNNR20072057.

Birhane, E., Ashfare, H., Fenta, A. A., Hishe, H., Gebremedhin, M. A., Wahed, H. G. and Solomon, N. (2019). Land use land cover changes along topographic gradients in Hugumburda national forest priority area, Northern Ethiopia. Remote Sensing Applications: Society and Environment, 13: 61-68. Blaikie, P. Cameron, J. and Seddon, J. D. (1980). Nepal in crisis: Growth and Stagnation at the Periphery. Oxford: Oxford University Press.

Blaikie, P. and Brookfield, H. (1987). Defining and debating the problem. In: P. Blaikie and H. Brookfield (Eds.), Land Degradation and Society. London: Methuen and Co. Ltd.

Blaschke, T. (2010). Object based image analysis for remote sensing. ISPRS Journal of Photogrammetry and Remote Sensing, 65: 2-16. 
C. L. Chidi*, W. Sulzer, P. K. Pradhan / The Geographical Journal of Nepal Vol. 12: 41-56, 2019

Carson, B. (1985). Erosion and sedimentation process in the Nepalese Himalaya, ICIMOD occasional paper no. 1. Kathmandu: International Center of Integrated Mountain Development (ICIMOD).

CBS (2012). National population and housing census 2011: (National Report). Kathmandu: Central Bureau of Statistics.

CBS (2013). National sample census of agriculture Nepal: National report. Kathmandu: Central Bureau of Statistics.

CBS, (2017). National climate change impact survey 2016: A statistical report. Kathmandu: Central Bureau of Statistics.

Chaudhary, S., Wang, Y., Khanal, N. R., Xu, P., Fu, B., Dixit, A. M., Yan, K., Liu, Q, and Lu, Y. (2018). Social impact of farmland abandonment and its eco-environmental vulnerability in the high mountain region of Nepal: A case study of Dordi river basin. Sustainability, 10 (2331): 1-19. doi:10.3390/su10072331w.

Chidi, C. L. (2015). Impact of out migration on land use change in Aroundi Khola watershed of Syangja, western Hill of Nepal. In: Mehata, R. B. (Ed.), Environmental Crisis, (First Edition). Ranchi: Institute of Social Development and Research.

Chidi, C. L. (2016). Determinants of cultivated land abandonment in the hills of western Nepal. In: D. Petrea, R. Rusu, S. Bilasco and T. Man (Eds.), Studiauniversitatis babes-bolyaigeographia, 61(LXI): 101-116.

Clarke, J. I. (1990). Mountain and man: An overview. In: A. Ahmad and J. I. Clark (Eds.), Mountain Population Pressure. New Delhi: Vikas Publishing House Pvt. Ltd.

DHM (2009). Climatological and agro-meteorological records of Nepal. Kathmandu: Department of Hydrology and Meteorology, Government of Nepal.

Ellis, E. C. (2004). Long term ecological changes in the densely populated rural landscape in China. In: R. S. DeFris, G. P. Asnera and R. A. Houghton (Eds.), Geophysical Monograph, 153: 303-320. Washington: American Geophysical Union.

ERDAS (2010), LPS User's Guide. ERDAS, Inc. Norcross, GA.

Eckholm, E. (1976). Losing ground, environment: Science and policy for sustainable development,18 (3), 6-11. doi: 10.1080/00139157.1976.9930747.

DADO (2013).Annual agriculture development programme and statistical book. Synagja: District Agriculture Development Office. 
C. L. Chidi*, W. Sulzer, P. K. Pradhan / The Geographical Journal of Nepal Vol. 12: 41-56, 2019

European Commission (2009). Peak performance; new insights into mountain farming in the European Union (Commission Staff Working Document), 1724 final. Brussels: Directorate-General for Agriculture and Rural Development.

Fatima, K. and Hussain, A. (2012). Problems and prospects of hill farming. Research Journal of Agricultural Sciences, 3 (2): 578-580.

FAO (2011). Why invest in sustainable mountain development. Rome: Food and Agriculture Organization of the United Nations.

Gellrich, M., Baur, P., Koch, B. and Zimmermann, N.E. (2007). Agricultural land abandonment and natural forest regrowth in the Swiss mountains: Apartially explicit economic analysis, Agriculture Ecosystem and Environment, 118: 93108.

GoN (2014). Nepal second national communication to United Nations framework convention on climate change. Kathmandu: Ministry of Science, technology and Environment, Government of Nepal.

Higgins, S., Mohan, M., and McDobagh, J. (2012). Interdisciplinary interpretation and application of the concept of scale in landscape research. Journal of Environmental Management, 113: 137-145.

Hua, X., Yan, J., Li, H., He, W., and Li, X. (2016). Wildlife damage and cultivated land abandonment: Findings from the mountainous areas of Chongqing, China. Crop Protection, 84: 141-149. doi: 10.1016/j.cropro.2016.03.005.

Ives, J. D. and Messerli, B. (1989). The himalayandilemma: Reconciling development and conservation. New York: Routledge.

Izquierdo, A. E., Grau, H. R., and Aide, T. M. (2011). Implication of rural urban migration for conservation of the Atlantic forest and urban growth Misiones Argentina (1970-2030). Ambio. Retrivedfrom:www.ncbi.nlm.nih.gov.pmc/articles.

Jupp, D, Dogbe, T. and Korboe, D. (2016). Reality check approach midterm study: Northern Ghana millennium village impact evaluation. ITAD.

Khanal, N. R. and Watanabe, T. (2006).Abandonment of agricultural land and its consequences. Mountain Research and Development, 26(1):32-40.

Lawali, R, and Dauda, W. A. (2014). Digital orthophoto generation with aerial photographs. Academic Journal of Interdisciplinary Studies, 3(7): 133-141. Rome: MCSER Publishing. Doi:10.5901/ajis.2014.v3n7p133.

Lillesand, T. M., Kiefer R. W. and Chipman, J. W. (2011). Remote sensing and image interpretation ( $6^{\text {th }}$ Edition). New Delhi: john Wiley and Sons, Inc. 
C. L. Chidi*, W. Sulzer, P. K. Pradhan / The Geographical Journal of Nepal Vol. 12: 41-56, 2019

Li, S., Tramberend, S., Li, X., Sun, L., Cao, G. and Fischer, G. (2018). An estimation of the extent of cropland abandonment in mountainous regions of China. Land degradation and development. doi: 10.1002/ldr.2924

Mackenzie, A., Ball, A. S., and Virdee, S. R. (2002). Instant notes in ecology. New Delhi: Viva Books Limited.

Mahat, T. B. S. (1985). Human impact on forests in the middle hills of Nepal,(Unpublished $\mathrm{PhD}$ thesis in forestry). Canberra: Australian National University.

Mauch, S.P. (1976). Energy situations in the hills: Imperative for development strategies. In: Mountain Environment and Development. Kathmandu: Sohayogi Press.

Mohan, C., Western, A. W., Wei, Y., and Saft, M. (2018). Predicting groundwater recharge for varying land cover and climate conditions - a global meta-study. Hydrology and Earth System Sciences, 22: 2689-2703.

NCCR/NIDS (2008), Migration year book 2007, Kathmandu: Nepal Institute of Development Studies.

Pradhan, P. K. and Sharma P. (2017). Land use change and its driving forces in the Koshi Hills, Eastern Nepal. In: Li, Ainong, Deng, Wei and Zhao, Wei (Eds.), Land Cover Change and Its Eco-environmental Responses in Nepal. Singapore: Springer Geography.

Pratap, T. (2011). Hill Agriculture: Challenges and opportunities. Indian Journal of Agriculture Economics, 66 (1): 33-52.

Prishchepov, A. V., Mullaer, D., Dubinin, M., Baumann, M. B., and Radeloff, V. C. (2013). Determinants of agricultural land abandonment in post-Soviet European Russia. Land Use Policy, 30, pp. 873- 884.

RAP (2015) Reality check approach base line report: Monitoring, evaluation and learning component. Kathmandu: Nepal Rural Access Programme.

Rieger, H. C. (1976). The Himalayas and the Ganges and an ecological system. In: Mountain Environment and Development. Kathmandu: Sohayogi Press.

Regmi, M. C. (1978). Land tenure and taxation in Nepal, I-IV. Kathmandu: Ratna Pustak Bhandar.

Schroder, R.F. (1977). Ecological changes in rural Nepal, (Published PhD thesis). Washington: University of Washington.

Shi, T., Li, X., Xin, L., and Xu, X. (2017). The spatial distribution of farmland abandonment and its influential factors at the township level: A case study in the mountainous area of China. Land Use Policy, 70: 510-520. 
Shreenivasulu, G., Jayaraju, N., Kishore, K., and Prasad, L. (2014). Land use and land cover analysis using remote sensing and GIS: a case study in and around Rajampet, Kadapa district, Andhra Pradesh, India. Indian Journal of Scientific Research, 8(1): 123 - 129.

Shengfa, L. and Xiubin, Li (2017). Global understanding of farmland abandonment: A review and prospects. Journal of Geographical Sciences, 27(9): 1123-1150. doi: 10.1007/s11442-017-1426-0.

Tukahirwa, J. M. B. (2002). Policies, people and land use change in Uganda: A case study in Ntungamo, Lake Mburo and Sango Bay Sites. Land Use Change Impacts and Dynamics (LUCID): Working paper series No. 17.

VanWey L. K. (2003). Land ownership as a determinant of temporary migration in Nang Rong, Thailand. European Journal of Population, 19: 121-145. 